\title{
Rhabdomyolysis secondary to drug interaction between atorvastatin, omeprazole, and dexamethasone
}

\author{
This article was published in the following Dove Press journal: \\ International Medical Case Reports Journal \\ 3 September 2012 \\ Number of times this article has been viewed
}

\author{
Shereen Elazzazy' \\ Saad S Eziada ${ }^{2}$ \\ Manal Zaidan' \\ 'Pharmacy Department, ${ }^{2}$ Oncology \\ Hematology Department, \\ National Center for Cancer Care \\ and Research, Hamad Medical \\ Corporation, Doha, Qatar
}

\begin{abstract}
Concomitant administration of atorvastatin, omeprazole, and dexamethasone has been shown to increase the serum concentration of serum hydroxymethylglutaryl coenzyme A which can be associated with elevation of creatine kinase and an increased risk of severe myopathy and rhabdomyolysis. In this paper, we report a case of a 60 -year-old female patient with stage IV colon cancer and compromised hepatic function receiving palliative care who developed rhabdomyolysis while taking atorvastatin, omeprazole, and dexamethasone. Atorvastatin was stopped, and the dexamethasone dose was decreased. Her case was complicated by urosepsis cultures revealing an extended spectrum $\beta$-lactamase-producing strain of Escherichia coli, and she died on the second day after admission. Physicians should evaluate the risk/benefit ratio of continuing statins in palliative care patients, and pay special attention to the monitoring of patients on statins and P-glycoprotein inhibitors regardless of hepatic function.
\end{abstract}

Keywords: statins, rhabdomyolysis, drug-drug interaction, P-glycoprotein inhibitors

\section{Introduction}

Rhabdomyolysis is a clinical syndrome in which skeletal muscle damage and necrosis leads to the release of intracellular contents of muscle. In severe cases, this can lead to extreme serum muscle enzyme elevations, electrolyte imbalances, renal failure, and death. ${ }^{1}$ The most common side effects of statins are skeletal muscle complaints, including clinically important myositis and rhabdomyolysis, mild serum creatine kinase elevations, myalgia with or without elevated creatine kinase, muscle weakness, muscle cramps, and persistent myalgia. ${ }^{2}$ The risk of rhabdomyolysis and other adverse effects of statin use can be exacerbated by several factors, including compromised hepatic and renal function, hypothyroidism, diabetes, and concomitant medications. ${ }^{2}$ Herein, we report a case of rhabdomyolysis due to concomitant administration of dexamethasone and omeprazole with atorvastatin in a patient without any precipitating factors.

\section{Case report}

A 60-year-old female patient on palliative care and known to have stage IV colon cancer with metastasis to the omentum, mesentery, bone and lung, as well as a focal hepatic lesion in segment VIII, was admitted to hospital with complaints of shortness of breath, lethargy, severe myalgia, and proximal muscle weakness of the extremities. A computed tomographic angiogram was done, which ruled out pulmonary embolism. She denied alcohol use, and vigorous physical exercise was very unlikely given her palliative care status. Her medications consisted of atorvastatin $20 \mathrm{mg}$ daily for hyperlipidemia which she had been taking for the previous 6 months, omeprazole $20 \mathrm{mg}$ daily for peptic ulcer
Correspondence: Shereen Elazzazy Pharmacy Department, National Center for Cancer Care and Research, Hamad Medical Corporation,

Doha, Qatar

Tel +9745500 962I

Email shereen_amin@yahoo.com 
Table I Laboratory values on admission and on day I after admission

\begin{tabular}{lll}
\hline Item & $\begin{array}{l}\text { On } \\
\text { admission }\end{array}$ & $\begin{array}{l}\text { Day after } \\
\text { admission }\end{array}$ \\
\hline ALT $(\mathrm{U} / \mathrm{L})$ & 74 & 81 \\
AST $(\mathrm{U} / \mathrm{L})$ & 160 & 181 \\
$\mathrm{LDH}(\mathrm{U} / \mathrm{L})$ & 622 & 595 \\
Total bilirubin $(\mu \mathrm{mol} / \mathrm{L})$ & 9 & 10 \\
Serum creatinine $(\mathrm{mmol} / \mathrm{L})$ & 33 & 38 \\
Urea nitrogen $(\mathrm{mmol} / \mathrm{L})$ & 10.4 & 9.2 \\
Potassium $(\mathrm{mmol} / \mathrm{L})$ & 4.6 & 4.6 \\
Sodium $(\mathrm{mmol} / \mathrm{L})$ & 134 & 138 \\
Blood glucose $(\mathrm{mmol} / \mathrm{L})$ & 5.6 & \\
Creatine kinase $(\mu / \mathrm{L})$ & Not tested & 5960 \\
Myoglobin $(\mathrm{ng} / \mathrm{mL})$ & Not tested & 4457 \\
Hemoglobin $(\mathrm{g} / \mathrm{dL})$ & 13 & 15 \\
White cell count $(/ \mu \mathrm{L})$ & 6200 & 1900 \\
Absolute neutrophil count $(/ \mu \mathrm{L})$ & 4700 & 1700 \\
International normalized ratio & 0.9 & 1.1
\end{tabular}

Abbreviations: ALT, alanine transferase; AST, aspartate transferase; $L D H$, lactate dehydrogenase.

prophylaxis, dexamethasone $8 \mathrm{mg}$ twice daily for spinal cord compression, calcium carbonate supplementation, tramadol for chronic cancer pain, celecoxib for bone pain, gabapentin for neuropathic pain, and bisacodyl for constipation. She had no prior personal history of thyroid disease or muscle disorders. She had no previous history of muscular toxicity with statin or fibrate use. Table 1 shows the patient's laboratory values on admission and 1 day after admission.

The diagnosis was rhabdomyolysis secondary to a drug interaction between omeprazole, dexamethasone, and atorvastatin. Atorvastatin was stopped, the dexamethasone dose was decreased to $6 \mathrm{mg}$ twice daily, and intravenous fluids were started immediately. Her case was complicated by urosepsis cultures revealing an extended spectrum $\beta$-lactamase-producing strain of Escherichia coli, and she died on the second day after admission.

\section{Discussion}

This report describes a patient with rhabdomyolysis secondary to a drug interaction between atorvastatin, omeprazole, and dexamethasone. Statins have been found to be effective in both primary and secondary prevention of coronary disease. ${ }^{3}$ Although statins are well tolerated by most patients, they may cause myopathy, rhabdomyolysis, and elevated liver enzymes. ${ }^{4}$ Proton pump (P-glycoprotein) inhibitors may increase serum hydroxymethylglutaryl coenzyme A (HMG-CoA) reductase inhibitor concentrations. ${ }^{5}$ At the same time, dexamethasone (a P-glycoprotein PGP/ABCB1 inhibitor) may increase serum concentrations of P-glycoprotein PGP/ABCB1 substrates like atorvastatin. P-glycoprotein inhibitors may also enhance the distribution of P-glycoprotein substrates to specific cells, tissues, and organs where P-glycoprotein is present in large amounts, eg, the brain, $\mathrm{T}$ lymphocytes, and the testes. ${ }^{6,7}$ However, data are conflicting regarding the role of P-glycoprotein in the disposition of atorvastatin, ${ }^{8-11}$ and the ability of proton pump inhibitors such as omeprazole to inhibit P-glycoprotein at therapeutic concentrations. ${ }^{12,13}$ There have been several case reports of rhabdomyolysis induced by medications which increase the serum concentration of HMG-CoA reductase inhibitors, ${ }^{4-7}$ but most of the reported cases were precipitated by exercise. ${ }^{14,15}$ Increased serum HMG-CoA concentrations can be associated with elevation of creatine kinase and an increased risk of severe myopathy and rhabdomyolysis. Due to the severe morbidity seen in this report, close monitoring is warranted when such agents are used in combination. In addition, given that many statins are substrates of P-glycoprotein, this mechanism needs further elaboration to prevent similar complications with use of this important class of drugs.

\section{Conclusion}

P-glycoprotein drug interactions with atorvastatin and other HMG-CoA reductase inhibitors, ie, statins, may be associated with unreported risks for rhabdomyolysis. Critical monitoring is warranted when such agents are used in combination. In addition, since many statins are substrates of P-glycoprotein, this mechanism needs further elaboration to prevent similar complications with use of this important class of drugs.

\section{Disclosure}

The authors declare no conflicts of interests in this work.

\section{References}

1. Tokinaga K, Oeda T, Suziki Y, Matsushima Y. HMG CoA reductase inhibitors might cause high elevations of creatine phosphokinase in patients with unnoticed hypothyroidism. Endocr J. 2006;53:401-405.

2. Thompson PD, Clarkson P, Karas RH. Statin-associated myopathy. JAMA. 2003;289:1681-1690.

3. Larosa JC, He J, Vupputuri S. Effect of statins on risk coronary disease. JAMA. 1999;282:2340-2346.

4. Omar MA, Willson JP, Cox TS. Rhabdomyolysis and HMG-COA reductase inhibitors. Ann Pharmacother. 2001;35:1096-1107.

5. Sipe BE, Jones RJ, Bokhart GH. Rhabdomyolysis causing AV blockade due to possible atorvastatin, esomeprazole, and clarithromycin interaction. Ann Pharmacother. 2003;37:808-811.

6. Kivisto KT, Niemi M, Fromm MF. Functional interaction of intestinal CYP3A4 and P-glycoprotein. Fundam Clin Pharmacol. 2004;18: 621-626.

7. Kim RB. Drugs as P-glycoprotein substrates, inhibitors, and inducers. Drug Metab Rev. 2002;34:47-54.

8. Chen C, Lin J, Smolarek T, et al. P-glycoprotein has differential effects on the disposition of statin acid and lactone forms in Mdr1 a/B knockout and wild-type mice. Drug Metab Dispos. 2007;35:1725-1729. 
9. Chen C, Mireles RJ, Campbell SD, et al. Differential interaction of 3-hydroxy-3-methylglutaryl-CoAreductase inhibitors with ABCB1, ABCC2, and OATP1b1. Drug Metab Dispos. 2005;33:537-546.

10. Hochman JH, Pudvah N, Qiu J, et al. Interactions of human P-glycoprotein with simvastatin, simvastatin acid, and atorvastatin. Pharm Res. 2004;21:1686-1691.

11. Wu X, Whitfield LR, Stewart BH. Atorvastatin transport in the Caco-2 cell model: contributions of P-glycoprotein and the protonmonocarboxylic acid co-transporter. Pharm Res. 2000;17:209-215.

12. Pauli-Magnus $\mathrm{C}$, Rekersbrink $\mathrm{S}$, Klotz $\mathrm{U}$, et al. Interaction of omeprazole, lansoprazole and pantoprazole with P-glycoprotein. Naunyn Schmiedebergs Arch Pharmacol. 2001;364:551-557.
13. Collett A, Tanianis-Hughes J, Carlson GL, et al. Comparison of P-glycoprotein-mediated drug-digoxin interactions in Caco-2 with human and rodent intestine: relevance to in vivo prediction. Eur J Pharm Sci. 2005;26:386-393.

14. Barahona MJ, Mauri A, Sucuzza N, Paredes R, Wanger AM. Hypothroidism as a cause of rhabdomyolysis. Endocr J. 2002;49: 621-623.

15. Riggs JE. Acute exertional rhabdomyolysis in hypothyroidism: the result of reversible defect in glycogenolysis. Mil Med. 1990;155: $171-172$.

\section{Publish your work in this journal}

The International Medical Case Reports Journal is an international, peer-reviewed open-access journal publishing original case reports from all medical specialties. Previously unpublished medical posters are also accepted relating to any area of clinical or preclinical science. Submissions should not normally exceed 2,000 words or
4 published pages including figures, diagrams and references. The manuscript management system is completely online and includes a very quick and fair peer-review system, which is all easy to use. Visit http://www.dovepress.com/testimonials.php to read real quotes from published authors.

Submit your manuscript here: http://www.dovepress.com/international-medical-case-reports-journal-journal 